\title{
The Unbearable Duration of Andy Warhol's Films
}

\author{
By Julian Jason Haladyn \\ Spring 2011 Issue of KINEMA
}

\section{EMPIRE OF BORING: THE UNBEARABLE DURATION OF ANDY WARHOL'S FILMS}

\begin{abstract}
I've been quoted a lot as saying, 'I like boring things.' Well I said it and I meant it. But that does
\end{abstract} not mean I'm not bored by them. ${ }^{(1)}$

\section{Warhol's Meaninglessness}

In his 1965 film Poor Little Rich Girl, Andy Warhol presents a motionless shot of Edie Sedgwick engaged in a series of everyday activities - talking on the telephone, modelling a new coat, and the like - the first 33minutes of which is presented out of focus. Having watched a number of Warhol's films, this opening sequence of formless shapes and disembodied voices stands out as the most difficult time I have spent attempting to "watch" a film. The difficulty with viewing Warhol's films in general stems from his employment of structuralist tactics, specifically filming with a static camera, using long-takes and not editing the film. As A. L. Rees states: "Warhol's laconic 'I just switch on the camera and walked away' sums up his attack on film as dream and metaphor." ${ }^{(2)}$ In the case of Poor Little Rich Girl, Warhol switched on the camera and walked away, leaving the image out of focus until he changed reels, at which point the focus was reinstated before he again walked away. Viewers may wish to read meaning into this absence of focus - interpreting this visible blur or blank as a representation of the unattainable dream of cinema - but Warhol actively undermines the possibility of believing that this meaning is intentional or part of the "purpose" of the scene. Given his working process, there is little doubt that this 33-minute blur of unfocused imagery is the result of a careless accident, which Warhol chose to leave as part of the final film. Such acts represent another of Warhol's structuralist tactics, in which he turns "towards the material aspect of film" in order to eliminate his own personal presence - in the form of aesthetic and technical choices - within the work. ${ }^{(3)}$ Through his working process, Warhol problematizes the experience of filmic temporality by exaggerating viewers' experiences of duration. When I first viewed Poor Little Rich Girl at Cinematheque Ontario in Toronto, the restlessness throughout the theatre, particularly during the blurred opening reel, was palpable: people were talking, moving in their seats, several individuals actually stood up and left. Even among the devoted that stayed to witness the picture come into focus, an event punctuated by a communal sigh, the duration of film was visibly trying. In fact, this is not an uncommon response to watching a (whole) Warhol film. Jonas Mekas in "Notes After Reseeing The Movies of Andy Warhol" recounts a similar response:

During the early years of the decade, the early period of Warhol's film work, whenever I went to a university, lecturing, I used to take one of Andy's films, usually Eat. And always the same thing used to happen. The film starts rolling, the audience sits quietly, for a minute or two. The catcalls and crack remarks begin. In the fourth or fifth minute, however, they begin to realize that I have no intention of stopping the film, and the reports from the back lines reach the front lines, that the reel is big (45 minutes). The most unsettling, however, is the fact that no amount of noise or cracks seems to do any harm to the film! Its nonchalant, obstinate and don't-give-adamn imperturbability on the screen seems to reject or absorb anything you can throw at it. It almost grows stronger with every whistle. So the students begin to leave the auditorium. After ten minutes or so the impatient ones leave or give up, others resign, and the rest of the show proceeds quietly. ${ }^{(4)}$

Applying Mekas' description of the films to the artist himself, we might speculate that as a filmmaker Warhol's "nonchalant, obstinate and don't-give-a-damn imperturbability...seems to reject or absorb anything you can throw at" him. The only response left to viewers is either to leave the film or "resign" oneself to enduring it. This idea of the viewer "resigning" her/himself to watching a Warhol film points to the nature of the difficulty presented within these works - a difficulty that I believe is an extension of the repetitious activities that constitute his artistic process in general. Namely, as Lars Svendsen states in A Philosophy of Boredom, Warhol's "uncompromising insistence on meaninglessness." (5) 
Warhol's economic or laconic processes and statements, such as the one quoted by Rees earlier - 'I just switch on the camera and walked away' - point to an increased need for spectators of his work to leave their roles as passive viewers who sit and watch the images pass them by, instead becoming active participants in making the film. Through his passive process of filmmaking, Warhol dispels the viewer's reliance upon the illusionism or fantasy of film by allowing the camera to capture mechanically whatever is located in front of the apparatus without further intervention on his part - in the form of moving the camera, stopping or repeating the shot, or even editing the final footage. In this manner, the viewer must participate in the creation of the film through their act of investing time and meaning into Warhol's uncompromisingly meaningless movies. As Mekas states, whereas art and "good entertainment are supposed to shake you up," a Warhol film "asks that it be shaken up; by you, filled up with ideas, by you!" (6) In other words, even though it is Warhol who frames the scene and films it with the mechanical apparatus of the camera, it is the spectator of the film that must to fill it with ideas and, more importantly, meaning. In an interview with Gretchen Berg, Warhol states: "My first films using the stationary objects were...made to help the audience get more acquainted with themselves. Usually, when you go to the movies, you sit in a fantasy world, but when you see something that disturbs you, you get more involved with the people next to you."(7) Here Warhol acknowledges the disturbance inherent in his films, which he directly opposes to the fantasy world of the "usual" cinematic experience. He continues this opposition stating: "You could do more things watching my movies than with other kinds of movies: you could eat and drink and smoke and cough and look away and then look back and they'd still be there." ${ }^{(8)}$ In this manner, Warhol is establishing his movies as catalysts for experience and meaning - be it personal and/or interpersonal - rather than as a source of experience and meaning in and of themselves.

Warhol's description of all the things that a viewer may engage in while watching his movies recalls Mekas' account of the screening of these films during his university lectures. I would specifically like to call attention to his statement regarding the film's "nonchalant, obstinate and don't-give-a-damn imperturbability on the screen seems to reject or absorb anything you can throw at it." ${ }^{(9)}$ Warhol appeared to be aware of this quality of his filmic work, as evidenced by his statements to Berg, using the indifference of the medium as a model for his own persona. "If you want to know all about Andy Warhol, just look at the surface: of my paintings and films and me, and there I am. There's nothing behind it," he tells Berg. ${ }^{(10)}$ This is another of Warhol's laconic statements, one that again points to his insistence on a lack of personal investment, interaction, and meaning in his working process. Like the consumer culture from which he appropriates much of the imagery, Warhol constructs himself and his artwork - which he presents as interchangeable as reducible to the meaningless surfaces they present. This image of art and subjectivity in contemporary culture represents a harsh contrast to the Romantic ideals of the early avant-garde. In fact, Svendsen argues that "Warhol's art returns to a pre-Romantic paradigm of art, where expressiveness is not a relevant category. Warhol's work deals with the inner abstraction of things, with everything appearing as a flat echo of itself and Warhol empowering their spiritual emptiness." ${ }^{(11)}$ With both artist and artwork presented as flat echoes of themselves, Warhol's technique of cinematic passivity and indifference empowers the viewer to take on the primary role in the creative act and produce the experience and meaning of the film, which is meaningless without them.

\section{Warhol's Boredom}

This brings us to an important question that is consistently overlooked: why do people leave during screenings of Warhol's films? Given that his movies present only minimal action, it seems unlikely that the difficulty facing viewers is one of interpretation or conceptual understanding; in fact, I believe it is safe to say that most people who see Eat know the plot of the film - if the term "plot" can be applied in this case - within the first minute or two of screening. Robert Indiana is eating a mushroom, slowly. The duration of this act is further heightened by Warhol's choice to screen the film at 16 frames per second rather than 24 frames per second, a technique that he uses in a number of his films. ${ }^{(12)}$ "Early Warhol movies emphasized the cinema as a medium for experiencing time, rather than movement or event."(13) Warhol accomplishes this act of emphasizing an experience of time by not allowing the movie to distract viewers through the illusionism of filmic movement or narrative based events. Instead, viewers engage in a project of endurance, in which the limits of viewing within the context of the cinema are tested. This provocation is summed up by Patrice Petro in Aftershocks of the New as a refusal of the political modernist "aesthetics of distraction, sensory stimulation, and shock," for which she gives the example of "Warhol's notoriously esoteric and nearly unwatchable early films: Eat 
(forty-five minutes of a man eating a mushroom), Kiss (one close-up after another of people kissing), Sleep (six hours of a man sleeping), and Empire (eight hours of the Empire State building)."(14) Petro frames her argument specifically in relation to an aesthetics of boredom, which I believe provides a possible answer to the question at hand. Is it possible that viewers leave during screenings of Warhol's films because they are simply bored?

It is significant that virtually none of the major studies on Warhol's films address the issue of boredom, particularly because the concept of being bored seems so integral to his project as an artist. According to Svendsen, Warhol is perhaps "the person who takes furthest the manifesto of decadence from Baudelaire, Huysmans and Wilde. He gained maximum benefit out of displaying his own boredom, wearing it like an expensive piece of jewellery."(15) Yet, writers actively avoid employing the term "boredom," even when it is clear that the concept is being hinted at or even used without using the word. For example, Mekas discusses the difficulty or problem in these films, stating that the viewer is "confronted with his own blank mind. Here is cinema that doesn't manipulate him, doesn't use force on him: he himself, the viewer, has to search, to ask questions, sometimes unconsciously, other times consciously, and still other times by throwing objects at the screen." (16) But, what does it mean for a viewer to be confronted with her/his "own blank mind"? Mekas frames this statement by pointing out that the film is not manipulating or using force on the viewer and, reciprocally, that the viewer is placed in the position of having to search, ask questions, and even respond physically to the screen - presumably in an act of frustration. If we assume that the viewer's "own blank mind" refers to a state of boredom, in which the viewer is undistracted and therefore left with her/his own thoughts, we can then explain why they search, ask questions, and "even throwing objects at the screen." The passivity of Warhol's films engenders irritation because of their intentional lack of visual and conceptual stimulation; the resulting experience can therefore be classified as boredom. In this way, if we examine Mekas' statement by equating the viewer's "own blank mind" with boredom, we witness the two alternatives that Warhol leaves us: first, viewers take an active role in creating the film as a meaningful cultural object, either through the means outlined by Mekas or by simply "resigning" to the experience, or second, they literally walk out of the film.

As Petro states, "an aesthetics of boredom retains the modernist impulse of provocation and calculated assault. (How long must one watch and wait until something actually happens? How much tedium can one possibly stand?) It nevertheless abandons the modernist fiction of the self-contained aesthetic object, precisely by exploring the temporal and psychic structures of perception itself." ${ }^{(17)}$ By not entertaining viewers, Warhol's films insightfully question the role and position of the spectator in the apparatus of cinema, specifically in relation to the production of personal meaning. "The word 'boring' is bound up with the word 'interesting'," Svendsen tells us, "It is not until the advent of Romanticism towards the end of the eighteenth century that the demand arises for life to be interesting, with the general claim that the self must realize itself." (18) Avant-garde strategies have, especially in the twentieth century, increasingly opposed the everyday desire for art to be entertaining or 'interesting', yet there has been a reluctance to fully embrace the 'boring' due to the perceived negative qualities of the state. In her text "The Issue of Boredom: Is It Interesting?" Frances Colpitt - specifically in relation to the repetitiveness of Warhol's work - states: "Boredom necessarily describes the spectator's state of mind rather than any characteristic of the object. The root of the problem is in the unpreparedness of the audience, most of whom were not familiar with the theoretical concerns of this highly conceptual art."(19) Given Warhol's insistence that he just switched "on the camera and walked away," it is likely that he would agree that the boredom of viewers necessarily describes their "state of mind rather than any characteristic of the object" since the object for Warhol is just a surface. The surface of Warhol's films test the depths of viewers, forcing them to abandon the passivity that mainstream commercial cinema engenders in favour of an active viewing position that challenges where the meaning of film is produced: in the cinematic apparatus, the artist, or in the individual consciousness of the viewer.

There is a blatant dichotomy between the critical writing on Warhol's films and the experience of sitting through one; I believe this is an aftereffect of his filmic process, in which he leaves it up to the viewer to create the experience and meaning of the work. "I'm interested in audience reaction to my films," Warhol tells Berg, "my films now will be experiments, in a certain way, on testing their reactions." (20) If Warhol is correct and his films test audience reactions, then the critical discussions of his work are traces of those reactions and therefore grounded in personal experience and meaning. As Svendsen states: "Warhol is beyond every 
form of alienation, since alienation always contains an echo of something allegedly authentic." ${ }^{(21)}$ In this manner, Warhol's films - as well as his artwork in general - also test the limits of critical reflection and artistic discourse, the textual results of which are all too often regarded as authentic, self-contained aesthetic objects. "This is why boredom offers such a useful conceptual language to begin thinking about the fading of the historical event and the status of history in twentieth-century representational forms. Indeed, similar to modernism and like gender, boredom is a term that appears fixed and yet whose meaning remains contested, open-ended, always in flux." (22) And this is why boredom offers such a useful conceptual language to begin thinking about Warhol's films, because the act of being bored while viewing his cinematic experiments facilitates the need for viewers to formulate their own experience and meaning out of the imagery that he provides.

\section{Notes}

1. Andy Warhol (and Pat Hatchett), POPism: The Warhol '60s (New York: Harcourt, 1980), 50.

2. A. L. Rees, A History of Experimental Film and Video (London: BFI Publishing, 2005), 69.

3. Ibid., 69.

4. Jonas Mekas, "Notes After Reseeing The Movies of Andy Warhol," Andy Warhol Film Factory, ed. Michael O'Pray (London: BFI Publishing, 1989), 40.

5. Lars Svendsen, A Philosophy of Boredom (London: Reaktion Books, 2005), 101.

6. Mekas, 39 .

7. Gretchen Berg, "Nothing to Lose: An Interview with Andy Warhol," Andy Warhol Film Factory, ed. Michael O'Pray (London: BFI Publishing, 1989), 58.

8. Ibid., 58.

9. Mekas, 39 .

10. Berg, 56.

11. Svendsen, 101.

12. Near the beginning of his text, Mekas dramatically retells the story of when he instructed Stan Brakhage to "sit down again and look at Eat and Sleep at 16 frames per second," after which he recalls that he had never seen Stan "so shaken up by another aesthetic world as he was that day after watching the movies of Andy Warhol." Mekas, 29-30.

13. Gregory Battcock, "Four Films by Andy Warhol," Andy Warhol Film Factory, ed. Michael O'Pray (London: BFI Publishing, 1989), 42.

14. Patrice Petro, Aftershocks of the New: Feminism and Film History (New Brunswick: Rutgers UP, 2002), 68 .

15. Svendsen, 106.

16. Mekas, 39. Although I am using this quote to reference the viewer in general, as either female or male, I feel it is important to acknowledge the masculine language employed by Mekas in defining the "viewer" of Warhol's films, particularly in light of his consistent presentation of women in these works. In the introduction to Andy Warhol Film Factory, the editor Michael O'Pray points to the lack of a feminist perspective within the volume and states that there is still much to say from a feminist point of view on Warhol. Michael O'Pray, Introduction, Andy Warhol Film Factory, ed. Michael O'Pray (London: BFI Publishing, 1989), 13. For a feminist analysis of Warhol's films, see Leanne Gilbertson's "Andy Warhol's Beauty \#2: Demystifying 
and Reabstracting the Feminine Mystique, Obliquely," Art Journal 62.1 (Spring 2003): 24-33.

17. Petro, 68.

18. Svendsen, 28.

19. Frances Colpitt, "The Issue of Boredom: Is It Interesting?" The Journal of Aesthetics and Art Criticism 43. 4 (Summer, 1985): 360.

20. Berg, 58.

21. Svendsen, 101.

22. Petro, 93.

\section{Author Information}

Julian Jason HALADYN is a Canadian writer and artist based in London, Ontario. He is the author of Marcel Duchamp: Étant donnés (Afterall Books, 2010), as well as a number of published texts on art and film. Haladyn presently teaches courses in Visual Arts at the University of Western Ontario. 